\section{Oxygenation of Irrigation Water during Propagation and Container Production of Bedding Plants}

\author{
Erin J. Yafuso and Paul R. Fisher ${ }^{1}$ \\ Environmental Horticulture, University of Florida, P.O. Box 110670, \\ Gainesville, FL 32611-0670
} Additional index words. Calibrachoa, greenhouse, Lobelia, oxygenation, Pelargonium,
rooting, water quality

\begin{abstract}
Oxygen supply to the root zone is essential for healthy plant growth, and one technology that can potentially supply additional oxygen is the injection of purified oxygen (oxygenation) into irrigation water. The objective was to evaluate whether oxygenation of irrigation water affected plant growth and substrate dissolved oxygen (DO) levels during mist propagation of unrooted cuttings and subsequent growth in containers. Dissolved oxygen measured at source tanks for ambient tap water (averaging $\left.7.1 \mathrm{mg} \cdot \mathrm{L}^{-1}\right)$ or oxygenated tap water $\left(31.1 \mathrm{mg} \cdot \mathrm{L}^{-1}\right)$ was pumped through fine $(69 \mu \mathrm{m})$ mist nozzles for propagation of Calibrachoa $\times$ hybrid 'Aloha Kona Dark Red' and Lobelia erinus 'Bella Aqua'. There were no measured differences in root length or root dry mass for Calibrachoa and Lobelia propagated using oxygenated water compared with ambient water because $D O$ of ambient or oxygenated water reached $\approx 100 \%$ oxygen saturation in water $\left(8.7 \mathrm{mg} \cdot \mathrm{L}^{-1}\right)$ after passing through mist nozzles. To evaluate subsequent growth without the effect on DO of fine emitters, rooted cuttings of these two plant species and Pelargonium $\times$ hortorum 'Patriot Red' were grown in $10.2-\mathrm{cm}$ diameter pots. The plants were irrigated with either ambient $\left(6.0 \mathrm{mg} \cdot \mathrm{L}^{-1}\right)$ or oxygenated $\left(27.7 \mathrm{mg} \cdot \mathrm{L}^{-1}\right)$ nutrient solutions, delivered by top watering or subirrigation when the substrate dried to $\approx 45 \%$ of container capacity (CC), measured gravimetrically. Oxygenated water did not enhance root or shoot growth compared with ambient water for the three bedding plants. In addition, Pelargonium growth was not enhanced when irrigated at high moisture level (maintained at $80 \% \mathrm{CC}$ ) with oxygenated water compared with ambient water. In container substrate without plants, it was possible to increase DO of the substrate solution by $68 \%$ when a high volume of oxygenated water $(200 \%$ container volume or $850 \mathrm{~mL}$ ) was applied by top watering because existing substrate solution was displaced. In contrast, when containers were subirrigated at $45 \% \mathrm{CC}$, the smaller 180-mL volume of oxygenated water was absorbed by the substrate and did not increase DO compared with ambient water. Overall, irrigating with oxygenated water did not enhance root or plant growth of three bedding plants grown in porous, peat-based substrate. To increase oxygen supply to roots in container production, growers should focus on having adequate air porosity in substrate and avoiding overwatering.
\end{abstract}

In container substrates, moisture level and substrate porosity affect oxygen supply to roots. Oxygen can be supplied to roots either as a gas present in air-filled pores or as DO in water. In atmospheric air, oxygen is at $20.9 \%$, equivalent to $274 \mathrm{mg} \cdot \mathrm{L}^{-1}$ at $1 \mathrm{~atm}$ and $25^{\circ} \mathrm{C}$. Within the root zone, Van Iersel and Dove (2014) pointed out that in a well-irrigated substrate, the relative humidity is likely to be close to $100 \%$, resulting in reduced partial pressure of oxygen because of water vapor $(19.1-20.6 \mathrm{kPa})$, and root and microbial respiration could further lower $\mathrm{O}_{2}$ concentration.

This research is supported by the National Institute of Food and Agriculture, U.S. Department of Agriculture, "Clean WateR3 - Reduce, Remediate, Recycle", \#2014-51181-22372. We thank our industry partners in the Floriculture Research Alliance (FloricultureAlliance.org) for their financial support and supply of materials.

We thank James C. Colee from UF Agriculture Statistics for providing statistical consulting.

${ }^{1}$ Corresponding author. E-mail: pfisher@ufl.edu.
Oxygen saturation concentration in water decreases as temperature increases, with 8.3 $\mathrm{mg} \cdot \mathrm{L}^{-1}$ saturated $\mathrm{DO}$ at $25^{\circ} \mathrm{C}$, compared with $11.3 \mathrm{mg} \cdot \mathrm{L}^{-1}$ at $10{ }^{\circ} \mathrm{C}$. The diffusion rate of oxygen in water is $\approx 10,000$ times slower than the diffusion in air (Colmer, 2003; Wegner, 2010). Consequently, transport of $\mathrm{O}_{2}$ in a substrate and availability for root uptake are dependent on factors that affect diffusion and advection (bulk flow) of oxygen, including the surface area of substrate particles and water that are in contact with air, the continuum of gas-filled pores, and substrate moisture level (Currie, 1970). Peat-based substrates are designed to avoid complete saturation and provide air-filled porosity for oxygen supply to roots, even when irrigated to CC (Argo et al., 1996; DeBoodt and Verdonck, 1971). In a typical peat-based substrate, air porosity can be up to $32 \%$ by volume at $\mathrm{CC}$ in a $1-\mathrm{L}$ container, but this percentage can decrease to $5 \%$ in small cells used for propagation of seedlings and unrooted cuttings (Argo et al., 1996;
Gislerod, 1982; Handreck and Black, 1994). Lower substrate oxygen conditions are likely to occur with fine substrate particles, small container size, and high moisture. These conditions may also occur during mist propagation of plant cuttings because high substrate moisture is needed to prevent plant wilting, there are frequent irrigation events, and plants are grown in small cells (Santos et al., 2011).

Oxygen supply to and within roots involves several processes and is vital for root physiological function. Diffusion and bulk flow of oxygen into container substrate often occurs rapidly, replacing oxygen used in respiration by roots and microbes (Van Iersel and Dove, 2014). Oxygen from air-filled pores can diffuse passively into the root tip (Lemon, 1962; Luxmoore et al., 1970) or DO can enter through water pathways (Luxmoore et al., 1970). Apoplastic porosity through contiguous intercellular spaces allows for the movement of oxygen within the root (Armstrong and Drew, 2002; Colmer, 2003). Channels in membranes or aquaporins also facilitate cell-to-cell symplastic transport of oxygen (Herrera and Garvin, 2011; Hub et al., 2009). These oxygen transport processes in the root allow the vital functions related to respiration and nutrient uptake to be carried out (Drew, 1988). Respiration rates have been estimated at $300-500 \mathrm{ng} \cdot \mathrm{cm}^{-3} \cdot \mathrm{s}^{-1}$ $0.3-0.5 \mathrm{ng} \cdot \mathrm{L}^{-1} \cdot \mathrm{s}^{-1}$ for apical regions of the root at $23{ }^{\circ} \mathrm{C}$ (Armstrong et al., 2000). Overirrigation fills substrate pores with water rather than air, and oxygen demand from respiring roots and microbes can further result in low (hypoxic) to no oxygen (anoxic) levels (Armstrong and Drew, 2002; Drew, 1983; Morard and Silvestre, 1996; Naasz et al., 2009). Plant stress has been observed in hydroponic production conditions under low DO concentrations from 0.1 to $2 \mathrm{mg} \cdot \mathrm{L}^{-1}$ (Goto et al., 1996; Zheng et al., 2007). Stress responses include decreased root metabolism and nutrient uptake, root death, and wilting (Armstrong and Drew, 2002; Drew, 1983; Ehret et al., 2010; Handreck and Black, 1994; Morard and Silvestre, 1996). Low oxygen at the root zone also increases the risk of diseases from microbial pathogens such as Pythium (Chérif et al., 1997).

In some studies, oxygenation of irrigation water has increased plant biomass. Dissolved oxygen in water can be increased with turbulence, bubbling of air or purified oxygen, and the addition of chemicals such as hydrogen peroxide (Schröder and Lieth, 2002). Oxygen injecting technology can increase DO above oxygen-saturated levels in irrigation water (Schröder and Lieth, 2002; Zheng et al., 2007). Lei et al. (2016) grew corn in vermiculite substrate under completely saturated conditions. Irrigating plants with oxygenated water (two aeration systems) increased the DO from 3.5 to $6.5 \mathrm{mg} \cdot \mathrm{L}^{-1}$, resulting in higher corn yield and biomass compared with those grown with ambient irrigation water with $0.3-4.5 \mathrm{mg} \cdot \mathrm{L}^{-1} \mathrm{DO}$. In a hydroponic system, when DO ranged from ambient of $\approx 8.5 \mathrm{mg} \cdot \mathrm{L}^{-1}$ to supersaturated $30 \mathrm{mg} \cdot \mathrm{L}^{-1}$, 
there were no effects on tomato dry mass (Zheng et al., 2007). In the Zheng et al. (2007) study, plant growth decreased and roots appeared stunted and thick when DO was further increased to $\approx 40 \mathrm{mg} \cdot \mathrm{L}^{-1}$. Although reports on oxygen injecting technology of irrigation water in propagation or container production of bedding plants are lacking, potential positive effects could include increased root or total growth and root health.

Our objective was to evaluate whether oxygenation of irrigation water affected plant growth and substrate DO levels during 1) mist propagation of unrooted cuttings and 2) subsequent growth in containers after transplant. Greenhouse experiments were run with mist propagation of vegetative cuttings of Calibrachoa $\times$ hybrida 'Aloha Kona Dark Red' and Lobelia erinus 'Bella Aqua' in plug trays. Plants of these two species and Pelargonium $\times$ hortorum 'Patriot Red' were subsequently grown to flowering in 10.2-cm-diameter containers. Supplemental experiments were conducted without plants to provide additional details on DO under the experimental growing conditions.

\section{Material and Methods}

Experiments were conducted in computercontrolled heated greenhouses at the University of Florida (UF) Environmental Horticulture Research Greenhouse Complex in Gainesville, FL. Atmospheric pressure used to calculate the DO solubility (http://water. usgs.gov/software/DOTABLES/) was provided by the UF Department of Physics Weather Station (http://www.phys.ufl.edu/ weather/). The water source for all experiments was greenhouse tap water, with an electrical conductivity (EC) of $0.4 \mathrm{mS} \cdot \mathrm{cm}^{-1}$ and $40 \mathrm{mg} \cdot \mathrm{L}^{-1} \mathrm{CaCO}_{3}$ alkalinity. The main water types were either ambient tap water (not oxygenated) or oxygenated tap water with injection of purified oxygen (Mazzei Aerous-8, San Luis Obispo, CA) as water passed through a bypass manifold at 6-7 $\mathrm{L} \cdot \mathrm{min}^{-1}$ into a contact tank to increase oxygen dissolution. Dissolved oxygen was measured with a multipoint factory-calibrated optical oxygen sensor (oxygen pressure) and temperature probe (Ocean Optics, Dunedin, FL).

\section{Experiment 1. Propagation}

Expt. 1A. Propagation plant trial. This experiment ran from 30 Mar. to 14 Apr. 2016, and aimed to measure the effect of two factors (water types and plant species) on rooting of vegetative plant cuttings. The experimental design was a split-plot design with water type as the main plot and plant species as the subplot. The water type (either ambient or oxygenated water) was randomly located in two irrigation zones on a bench and was replicated over four benches. Within an irrigation zone (a particular water type delivered onto a particular bench), there were two randomly positioned 51-count plug strip trays for each of the two species (Calibrachoa or Lobelia). To measure growth, root and shoot data were collected at two time periods (day 7 and 14). During the trial, ambient and oxygenated water flowed into unpressurized 18.9-L source tanks every $1.75 \mathrm{~h}$ for $5 \mathrm{~min}$ (sufficient to completely replace the stored solution). Water was then pumped at $310 \mathrm{kPa}$ from the source tank to irrigation lines using a subpump to a computer-controlled solenoid valve that allowed mist to be applied to the bench through $69-\mu \mathrm{m}$-diameter propagation nozzles (Coolnet Pro Fogger, Netafim, Israel). There were three propagation nozzles per irrigation zone, and the nozzles were spaced $61 \mathrm{~cm}$ between each nozzle and $61 \mathrm{~cm}$ above the bench.

Calibrachoa $\times$ hybrida 'Aloha Kona Dark Red' and Lobelia erinus 'Bella Aqua' were supplied as unrooted cuttings by Dümmen Orange (Las Mercedes, El Salvador). The unrooted cuttings were transplanted into 102count plug trays with $25 \mathrm{~mm}$ diameter cells (20.3 mL volume per cell) filled with a 60 peat:40 perlite $(\mathrm{v} / \mathrm{v})$ substrate. A porosity test on three replicate trays each with 18 cells resulted in an average of $8 \%$ air porosity, $69 \%$ water porosity, $23 \%$ solid, bulk density of $114 \mathrm{~g} \cdot \mathrm{L}^{-1}$, and water-holding capacity of $14 \mathrm{~mL} /$ cell. A surfactant (Capsil; Aquatrols, Paulsboro, NJ) was applied to plant foliage at $0.31 \mathrm{~mL} \cdot \mathrm{L}^{-1}$ to transplanted plant cuttings to reduce surface tension for more even distribution of water on the leaf surface and thereby reduced water loss in the cutting. Irrigation frequency averaged at $26 \mathrm{~min}$ for $10 \mathrm{~s}$ during week 1 and decreased to $2 \mathrm{~h}$ for $10 \mathrm{~s}$ during week 2 from 7:00 AM to 7:00 PM. At night, irrigation frequency averaged at $23 \mathrm{~min}$ for $10 \mathrm{~s}$ on days 1 to 3 and decreased to $1.3 \mathrm{~h}$ for $10 \mathrm{~s}$ on days 4 to 7 , with no night irrigation during week 2 .

The average DO and temperature spotchecked during daylight hours from the source tank for ambient water equaled 7.0 and $31.1 \mathrm{mg} \cdot \mathrm{L}^{-1}$ for oxygenated water at an average water temperature of $23{ }^{\circ} \mathrm{C}$. Air temperature averaged to $21.4{ }^{\circ} \mathrm{C}$, relative humidity was $72 \%$, and daily light integral photosynthetically active radiation $(P A R)$ was $9.9 \mathrm{~mol} \cdot \mathrm{m}^{-2} \cdot \mathrm{d}^{-1}$. Six plants per replicate tray were destructively sampled on day 7 and 14. Total root length per plant (representing the sum of primary adventitious roots emerging from the stem but not including secondary branched roots) was measured with a ruler. An average total root length per plant was calculated for each replicate tray. Root and shoot dry mass per plant were also averaged for each replicate tray. The bench and bench $\times$ water type interaction were considered as random effects, and water type, species, and time, and their interactions were considered as fixed effects and were analyzed using PROC GLIMMIX in SAS (SAS Version 9.4; SAS Institute, Cary, NC), with Tukey's honestly significant difference at $P=0.05$ for mean separation.

Expt. 1B. Persistence of supersaturated $D O$ in water over time. A factorial experiment was run to study the effect of water type and water movement on DO level over time. The water type was either ambient tap or oxygenated water held in an unpressurized 18.9-L container. Water movement was either controlled by a submersible pump at $378.5 \mathrm{~L} \cdot \mathrm{h}^{-1}$ or water was not stirred. There were three replicate containers for each factorial combination of water type and water movement. Dissolved oxygen was measured at $4-\mathrm{cm}$ depth from the surface over time $(0$, $30,90,150,210$, and $270 \mathrm{~min}$ ). Data were analyzed by three-way analysis of variance (ANOVA) using PROC GLIMMIX, with Tukey's honestly significant difference for mean separation in SAS.

Expt. 1C. Dissolved oxygen measured under propagation trial conditions. The change in DO was measured as water flowed through the irrigation system used in Expt. 1A. There were two factors a) water type, which included either ambient or oxygenated water, as described in Expt. 1A, and b) the irrigation location, which was a point within the irrigation line where the DO was measured including 1) the initial $18.9 \mathrm{~L}$ "source tank," 2) "bench no nozzle," where water was pumped from the source tank through 1.9-cm-diameter tubing and then $1.3-\mathrm{cm}$ diameter tubing into a collection container on the bench, and 3) a "bench with nozzle," where water was pumped from the source tank through $1.9-\mathrm{cm}$ tubing and then through the $69-\mu \mathrm{m}$ propagation nozzles and into a collection container on the bench. The experiment was carried out in a completely randomized order of the factorial combinations of water type (main plot) and irrigation location (subplot), and the experiment ("block") was repeated four times. Dissolved oxygen was measured immediately after the water collected on the bench. Data were analyzed by two-way ANOVA using PROC GLIMMIX with water type, irrigation location, and their interactions as fixed effects, and block $\times$ water type as a random effect, with Tukey's honestly significant difference for mean separation in SAS.

Expt. 1D. Dissolved oxygen measured in propagation cells. The effect of two factors (two water types and five applied volumes of water) on DO was quantified in the root substrate described for Expt. 1A in propagation cells. The water type was either ambient or oxygenated water, as described in Expt. $1 \mathrm{~A}$, averaging $7.1 \mathrm{mg} \cdot \mathrm{L}^{-1}$ at $22.2^{\circ} \mathrm{C}$ or 31.5 $\mathrm{mg} \cdot \mathrm{L}^{-1}$ at $22.7^{\circ} \mathrm{C}$, respectively. The applied volume of water added to the substrate was based on percent container volume from $0 \%$ (0 mL/cell), 25\% (5 mL), 50\% (10 mL), $100 \%(20 \mathrm{~mL})$, and $200 \%(40 \mathrm{~mL})$. The highest applied volume of water was $40 \mathrm{~mL}$ per cell, which represented $285 \%$ of the water holding capacity $(14 \mathrm{~mL} / \mathrm{cell})$. The experiment was a factorial design where each of the 10 combinations of water type and applied water volume were measured in random order, and the experiment ("block") was carried out five times. Before applying a water type, the container substrate was subirrigated to saturation and allowed to drain for $15 \mathrm{~min}$ to reach $\mathrm{CC}$. The water type was then poured onto the substrate surface. A toothpick was 
used to indent the substrate before inserting the oxygen sensor. The DO was measured immediately at $1-\mathrm{cm}$ depth from the surface of the substrate with the oxygen sensor and temperature probe, allowing the oxygen sensor to stabilize (minimum of $40 \mathrm{~s}$ ) before recording a measurement. Data were analyzed by two-way ANOVA using PROC GLIMMIX where water type, applied water volume, and their interactions were fixed effects, block $\times$ water type and block $\times$ applied water volume were random effects, and Tukey's honestly significant difference was used for mean separation.

\section{Experiment 2. Dissolved oxygen in 10.2-cm-diameter pots}

Expt. 2A. Container plant trial. This trial, conducted from 13 Apr. to 12 May 2016, aimed to measure the effect of water type and irrigation delivery methods on rooting, and plant growth was tested for each of three plant species. The water types (ambient and oxygenated water) were supplemented with nutrients $\left(17.0 \mathrm{~N}-1.7 \mathrm{P}-14.1 \mathrm{~K}\right.$ at $150 \mathrm{mg} \cdot \mathrm{L}^{-1}$ $\mathrm{N})$. The irrigation delivery method was either a) top watering, where $180 \mathrm{~mL}$ of nutrient solution was poured onto the container substrate surface or b) subirrigation, where 180 $\mathrm{mL}$ of nutrient solution was applied in a 12.7$\mathrm{cm}$-diameter saucer holding the pot. Plant species included the same Calibrachoa and Lobelia cultivars from Expt. 1A., and Pelargonium $\times$ hortorum 'Patriot Red'. The experiment was a randomized complete block design with a total of four blocks (benches) and two replicate pots per block for each combination of water type, irrigation delivery method, and plant species. Rooted cuttings of each species were transplanted into $10.2-\mathrm{cm}$ diameter pots $(425 \mathrm{~mL} /$ pot $)$ filled with peat: perlite $(60: 40 \mathrm{v} / \mathrm{v})$ substrate. Weight of six randomly selected pots was continuously logged using a weight scale and was manually checked several times each day. The plants were irrigated at $45 \%$ of CC measured gravimetrically, resulting in a total of 11 irrigation events during the trial. Irrigation at this moisture level is a typical research practice to provide water to bedding plants before wilting point, for example Johnson et al. (2013). Plant chlorophyll content was measured on the second fully expanded leaf with the average of three measurements per plant using a Minolta SPAD $502 \mathrm{~m}$ (Konica Minolta, Osaka, Japan). The plants were destructively sampled after four weeks, with eight replicate plants per water type, irrigation delivery, and species combination. The total root length was measured on a root scan using a root image analysis program (WinRHIZO Pro v. 2007a; Regent Instruments, Quebec, Canada), and dry mass of root and shoot were measured. Data were analyzed separately for each species by two-way ANOVA using PROC GLIMMIX with water type, irrigation delivery, and their interactions analyzed as fixed effects.

A porosity test for six replicate substratefilled pots resulted in an average $19 \%$ air porosity, $57 \%$ water porosity, $24 \%$ solid,

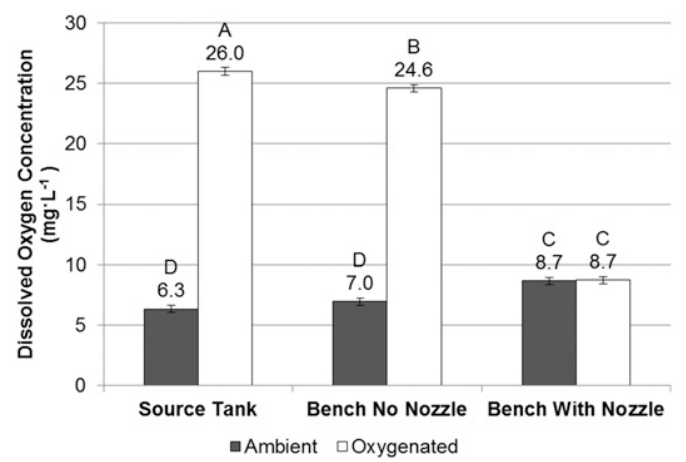

Fig. 1. The effect of water type (ambient water or oxygenated water) and irrigation points (source tank, a bench with no propagation nozzle, or a bench with a mist propagation nozzle) on dissolved oxygen concentration in Expt. 1C. Data are least square means of four replicates. Mean separation letters using Tukey's honestly significant difference at $\alpha=0.05$ and error bars indicate $\pm 95 \%$ confidence intervals.

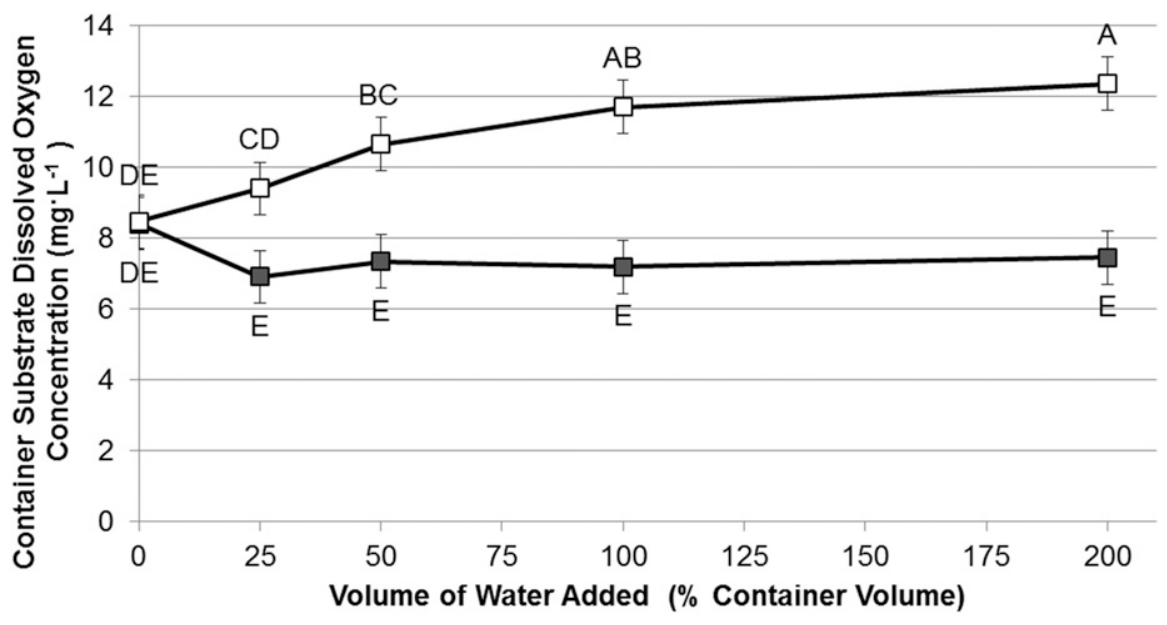

$\neg$-Ambient $-\square$-Oxygenated

Fig. 2. The effect of water type (ambient water or oxygenated water) and volume of water added $(0 \%, 25 \%$, $50 \%, 100 \%$, or $200 \%$ of container volume) on substrate oxygen measured at 1 -cm depth in plug cells (25-mm diameter) in Expt. 1D. Data are least square means of five replicates. Mean separation letters using Tukey's honestly significant difference at $\alpha=0.05$ and error bars indicate $\pm 95 \%$ confidence intervals.

bulk density of $110 \mathrm{~g} \cdot \mathrm{L}^{-1}$, and water holding capacity of $243 \mathrm{~mL}$. The average DO for the ambient water source was $6.0 \mathrm{mg} \cdot \mathrm{L}^{-1}$ at $26.3{ }^{\circ} \mathrm{C}, \mathrm{pH}$ was 6.8 , and $\mathrm{EC}$ was 1.4 $\mu \mathrm{S} \cdot \mathrm{cm}^{-1}$. The average DO for the oxygenated water source was $27.7 \mathrm{mg} \cdot \mathrm{L}^{-1}$ at $26.5^{\circ} \mathrm{C}$, the $\mathrm{pH}$ was 7.0, and EC was $1.4 \mu \mathrm{S} \cdot \mathrm{cm}^{-1}$. Daily averages of data collected each minute for air temperature was $22.7{ }^{\circ} \mathrm{C}$, relative humidity averaged $78 \%$, and daily light integral of $P A R$ was $17.1 \mathrm{~mol} \cdot \mathrm{m}^{-2} \cdot \mathrm{d}^{-1}$.

Expt. 2B. Subirrigation with Pelargonium at medium and high moisture level. To test whether oxygenated water would affect plant growth at high moisture level, two factors (two water types and two moisture levels) were varied to assess the effect on root and plant growth of Pelargonium. This trial was carried out simultaneously with Expt. 2A, and the water types were either ambient or oxygenated water described in Expt. 2A. The two moisture levels were managed by subirrigating when the average weight of six pots weighed the equivalent of $45 \%$ of CC measured gravimetrically to provide a medium moisture level or at $80 \% \mathrm{CC}$ for the high moisture level. The experiment was a completely randomized design with eight replicate pots per treatment combination of water type and moisture level. The plants were subirrigated with $180 \mathrm{~mL}$ of nutrient solution per irrigation event as described in Expt. 2A. There were 11 or 18 irrigation events for the medium or high moisture levels, respectively. The same plant data were collected as in Expt. 2A and were analyzed by two-way ANOVA using PROC GLIMMIX where water type, moisture level, and their interactions analyzed as fixed effects.

Expt. 2C. Dissolved oxygen in substrate with top watering. To assess the persistence of DO in substrate without plants, a threefactor (two water types, five volumes of applied water, and two measured depths) experiment was carried out. The water types were either ambient or oxygenated tap water. The average DO for ambient water and oxygenated water sources was $6.8 \mathrm{mg} \cdot \mathrm{L}^{-1}$ at $22.5{ }^{\circ} \mathrm{C}$ and $31.0 \mathrm{mg} \cdot \mathrm{L}^{-1}$ at $22.9{ }^{\circ} \mathrm{C}$, respectively. The volume of applied water poured onto the substrate surface was $0 \%(0$ $\mathrm{mL}), 25 \%$ (106 mL), 50\% (212 mL), 100\% 
Table 1. Results of the container trial showing the effect of water type (ambient water or oxygenated water) and water delivery method (top watered or subirrigation) on root length and plant dry mass (Expt. 2A). Data were analyzed separately for each of the three species. The least square means are from eight replicates. Analysis of variance (ANOVA) summary for treatment effects at a significant difference of $\alpha=0.05$.

\begin{tabular}{|c|c|c|c|c|c|}
\hline Plant species & Water type & Water delivery & Root length $(\mathrm{cm})$ & Shoot dry mass (g) & Root dry mass (g) \\
\hline Calibrachoa & Ambient & Top watered & 2,277 & 2.98 & 0.22 \\
\hline Calibrachoa & Oxygenated & Top watered & 2,320 & 3.08 & 0.21 \\
\hline Calibrachoa & Ambient & Subirrigated & 1,896 & 2.47 & 0.16 \\
\hline Calibrachoa & Oxygenated & Subirrigated & 1,923 & 2.84 & 0.19 \\
\hline \multicolumn{6}{|c|}{ Summary of ANOVA analysis for Calibrachoa } \\
\hline \multicolumn{2}{|l|}{ Water type } & & NS & NS & NS \\
\hline \multicolumn{2}{|c|}{ Water delivery } & & $*$ & NS & $*$ \\
\hline \multicolumn{2}{|c|}{ Water type $\times$ water delivery } & & NS & NS & NS \\
\hline Lobelia & Ambient & Top watered & 2,917 & 2.14 & 0.30 \\
\hline Lobelia & Oxygenated & Top watered & 2,685 & 1.90 & 0.26 \\
\hline Lobelia & Ambient & Subirrigated & 2,748 & 1.99 & 0.28 \\
\hline Lobelia & Oxygenated & Subirrigated & 2,361 & 1.91 & 0.23 \\
\hline \multicolumn{6}{|c|}{ Summary of ANOVA analysis for Lobelia } \\
\hline \multicolumn{2}{|l|}{ Water type } & & NS & $*$ & $*$ \\
\hline \multicolumn{2}{|c|}{ Water delivery } & & NS & NS & NS \\
\hline \multicolumn{2}{|c|}{ Water type $\times$ water delivery } & & NS & NS & NS \\
\hline Pelargonium & Ambient & Top watered & 1,424 & 5.56 & 0.33 \\
\hline Pelargonium & Oxygenated & Top watered & 1,544 & 5.87 & 0.34 \\
\hline Pelargonium & Ambient & Subirrigated & 1,431 & 5.63 & 0.35 \\
\hline Pelargonium & Oxygenated & Subirrigated & 1,408 & 5.54 & 0.33 \\
\hline \multicolumn{6}{|c|}{ Summary of ANOVA analysis for Pelargonium } \\
\hline \multicolumn{2}{|l|}{ Water type } & & NS & NS & NS \\
\hline \multicolumn{2}{|c|}{ Water delivery } & & NS & NS & NS \\
\hline \multicolumn{2}{|c|}{ Water type $\times$ water delivery } & & NS & NS & NS \\
\hline
\end{tabular}

NS $=$ no significance; $*=$ significant at $P=0.05$ level.

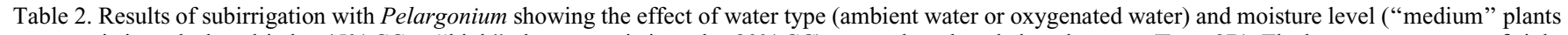
were irrigated when dried to $45 \% \mathrm{CC}$ or "high" plants were irrigated at $80 \% \mathrm{CC}$ ) on root length and plant dry mass (Expt. $2 \mathrm{~B}$ ). The least square means of eight replicates. Analysis of variance (ANOVA) summary for treatment effects at a significant difference of $\alpha=0.05$.

\begin{tabular}{|c|c|c|c|c|c|}
\hline Plant species & Water type & Moisture level & Root length (cm) & Shoot dry mass $(\mathrm{g})$ & Root dry mass $(\mathrm{g})$ \\
\hline Pelargonium & Ambient & Medium & 1,273 & 4.97 & 0.41 \\
\hline Pelargonium & Oxygenated & Medium & 1,236 & 4.91 & 0.42 \\
\hline Pelargonium & Ambient & High & 1,608 & 6.03 & 0.50 \\
\hline Pelargonium & Oxygenated & High & 1,566 & 5.12 & 0.45 \\
\hline \multicolumn{6}{|c|}{ Summary of ANOVA analysis } \\
\hline \multicolumn{2}{|l|}{ Water type } & & NS & NS & NS \\
\hline \multicolumn{2}{|c|}{ Moisture level } & & $* *$ & NS & $*$ \\
\hline \multicolumn{2}{|c|}{ Water type $\times$ moisture level } & & NS & NS & NS \\
\hline
\end{tabular}

NS $=$ no significance; $*=$ significant at $P=0.05$ level; $* *=$ significant at $P=0.005$ level.

(425 mL), or $200 \%(850 \mathrm{~mL})$ of container volume. The highest volume of $850 \mathrm{~mL}$ represented $350 \%$ of $\mathrm{CC}$. The experiment was a factorial experiment where all treatment combinations of water type (main plot), applied volume of water (subplot), and DO were measured at two depths in each pot (sub-sub-plot) in a randomized order, and the experiment was repeated five times. The container substrate was subirrigated and drained for $15 \mathrm{~min}$ to bring to CC before applying the water treatment. The DO was immediately measured in the substrate at 2and 4-cm depth from the surface of the substrate with an oxygen sensor and temperature probe using the procedure in Expt. 1D. Data were analyzed by three-way ANOVA using PROC GLIMMIX with water type, volume, depth, and their interactions as fixed effects and block $\times$ water type $\times$ volume as a random effect, and Tukey's honestly significant difference was used for mean separation.
Expt. 2D. Dissolved oxygen in substrate with subirrigation over time. To assess the irrigation delivery of subirrigation on the substrate DO, a three-factor (two water types, three measured depths, and four time periods) experiment was carried out. The water types were either ambient or oxygenated tap water. The average DO measured for ambient water and oxygenated water sources was $6.1 \mathrm{mg} \cdot \mathrm{L}^{-1}$ at $26.8{ }^{\circ} \mathrm{C}$ and $25.1 \mathrm{mg} \cdot \mathrm{L}^{-1}$ at $26.5{ }^{\circ} \mathrm{C}$, respectively. The measured depths were 2 , 4 , or $6 \mathrm{~cm}$ below the substrate surface and time periods were $0,30,60$, or $120 \mathrm{~min}$ (after an initial 15-min subirrigation). All combinations of water type (main plot) and three DO measurement depths (subplot) in each container were measured in a random order at each of the four time periods. Each container was only measured at one time period (destructive sampling). There were five experimental runs ("blocks"). DO was measured in a slightly different manner from other experiments to avoid damaging the oxygen sensor, by surrounding the probe with a plastic cylinder that was open at the measurement point. Data were analyzed by ANOVA using PROC GLIMMIX with water type, time, depth, and their interactions analyzed as fixed effects and block $\times$ water type $\times$ time as a random effect, with Tukey's honestly significant difference for mean separation.

\section{Results}

\section{Expt. 1. Propagation}

Expt. 1A. Propagation plant trial. Oxygenation of irrigation water did not affect root length, shoot dry mass, root dry mass, or total dry mass compared with ambient water. There were no significant differences within species for water type and interaction of water type by species. All plants were observed to have roots by day 7 , with total root length averaging $8.8 \mathrm{~cm} /$ plant for Calibrachoa 


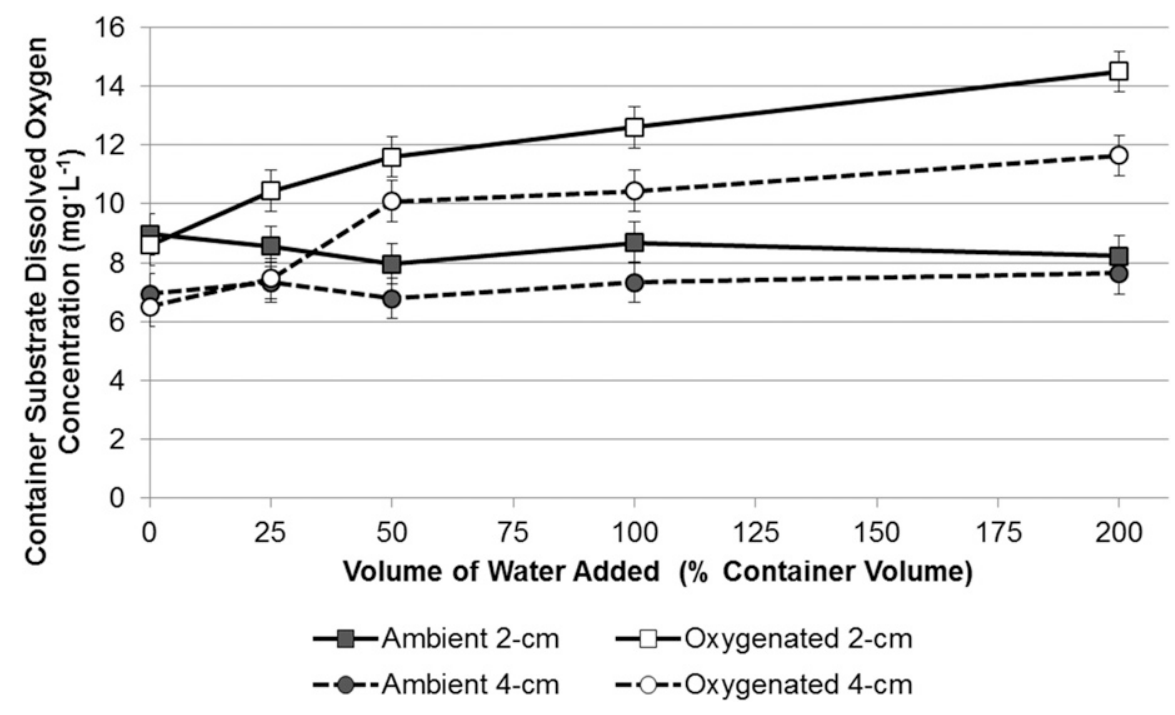

Fig. 3. The effect of water type (ambient water or oxygenated water) and volume of water added $(0 \%, 25 \%$, $50 \%, 100 \%$, or $200 \%$ of container volume) on substrate oxygen compared at 2- or 4-cm measured depth in pots (10.2-cm diameter) in Expt. 2C. Data are least square means of five replicates. Significant difference was at $\alpha=0.05$ and error bars indicate $\pm 95 \%$ confidence intervals.

and $7.3 \mathrm{~cm} /$ plant for Lobelia. Calibrachoa had greater total dry mass of $0.052 \mathrm{~g} / \mathrm{plant}$ at day 7 compared with Lobelia with $0.019 \mathrm{~g} /$ plant $(P=0.0001)$. By day 14 , total root length had increased to $125 \mathrm{~cm}$ for Calibrachoa with a total dry mass of $0.092 \mathrm{~g} /$ plant and a shoot to root ratio of 4.3. Lobelia had a total root length of $75 \mathrm{~cm}$ on day 14 , a total dry mass of 0.038 $\mathrm{g} / \mathrm{plant}$, and a shoot to root ratio of 2.3. Total dry mass of Calibrachoa was greater by $142.1 \%$ than Lobelia, resulting in a species difference $(P=0.0001)$. Plants appeared vigorous and healthy in all treatments.

Expt. 1B. Persistence of supersaturated DO in water over time. There were significant main effects for water type, water movement, time, and interaction effects of water type $\times$ water movement and water type $\times$ time $(P<$ $0.01)$. For ambient tap water, the DO level was unaffected by time or water movement and averaged to $7.1 \pm 0.05 \mathrm{mg} \cdot \mathrm{L}^{-1}$ (mean \pm standard error). For oxygenated water that was not stirred, DO was initially $28.3 \mathrm{mg} \cdot \mathrm{L}^{-1}$, and the measured level of $26.5 \mathrm{mg} \cdot \mathrm{L}^{-1}$ after $270 \mathrm{~min}$ was not significantly lower than the initial DO. For oxygenated water that was stirred, DO decreased from an initial $26.8-16.9 \mathrm{mg} \cdot \mathrm{L}^{-1}$ (a $37 \%$ decrease) after $270 \mathrm{~min}$. Oxygenated water that was stirred had a greater decrease in DO over time than oxygenated water that was not stirred. However, both stirred and nonstirred treatments remained supersaturated at $208 \%$ and $324 \%$ oxygen saturation, respectively, after $270 \mathrm{~min}$ at $24^{\circ} \mathrm{C}$.

Expt. 1C. Dissolved oxygen under propagation trial conditions. The DO measured in irrigation water at different points in the propagation system (Fig. 1) had a significant interaction between water type and irrigation point $(P=0.0001)$. Oxygenated water decreased slightly from the source tank $(26.0$ $\left.\mathrm{mg} \cdot \mathrm{L}^{-1}\right)$ to the "bench no nozzle" $\left(24.6 \mathrm{mg} \cdot \mathrm{L}^{-1}\right.$ ), and greatly decreased to $8.7 \mathrm{mg} \cdot \mathrm{L}^{-1}$ at the "bench with nozzle." Ambient water did not differ in DO between the source tank (6.3 $\left.\mathrm{mg} \cdot \mathrm{L}^{-1}\right)$ and "bench no nozzle" $\left(7.0 \mathrm{mg} \cdot \mathrm{L}^{-1}\right)$ but increased to $8.7 \mathrm{mg} \cdot \mathrm{L}^{-1}$ at the "bench with nozzle." Dissolved oxygen was $\approx 100 \%$ of saturation at the "bench with nozzle" measurement point, regardless of the water type, which is the likely reason that water oxygenation did not affect plant growth in Expt. 1A. The mist nozzle (with a $69-\mu \mathrm{m}$-diameter orifice reported by the manufacturer) produced fine water droplets, thereby increasing the surface area exposed to air. As a result, we hypothesize that increased DO levels in ambient water and offgassing of oxygen in oxygenated water occurred. In an unpublished study, we measured DO at a commercial greenhouse in North Carolina and similarly found that although well water at the source tank was $74 \%$ of saturation, after water passed through a $200-\mu \mathrm{m}$ mist nozzle (XR 11002; TeeJet, Wheaton, IL), the DO increased to $\approx 100 \%$ of saturation. Irrigation nozzles have previously been reported to increase DO concentration by increasing the droplet surface area exposure and movement in air (Schröder, 1994; Schröder and Lieth, 2002; Vestergaard, 1984; Wever et al., 2001).

Expt. 1D. Dissolved oxygen measured in propagation cells. In plug cells, the addition of oxygenated water increased the measured substrate DO (Fig. 2) from 8.5 to $12.3 \mathrm{mg} \cdot \mathrm{L}^{-1}$ (a $46 \%$ increase in oxygen) as the applied volume of water increased from $0 \%$ to $200 \%$ of container volume. There was a positive relationship between increasing applied volume of oxygenated water and the substrate DO in plug cells. The addition of ambient water did not change the substrate DO, which averaged $7.5 \mathrm{mg} \cdot \mathrm{L}^{-1}$ across the applied volumes of water.

\section{Expt. 2. Dissolved oxygen in 10-cm-diameter} pots

Expt. 2A. Container plant trial. Overall, oxygenated water did not increase the root or plant growth in any of the three bedding plants (Table 1). There was an increase measured in shoot dry mass of $8.3 \%(P=$ $0.032)$ and $17 \%$ root dry mass $(P=0.012)$ for Lobelia with ambient water compared with oxygenated water. Top-watered plants had greater root growth by $20.4 \%$ increase in total root length $(P=0.047)$ and $21.8 \%$ increase for root dry mass $(P=0.035)$ compared with subirrigation delivery method for Calibrachoa.

Expt. 2B. Subirrigation with Pelargonium at medium and high moisture level. There were no effects of water type on plant growth (Table 2). Similarly, there was no interaction between water type and substrate moisture level on plant growth. A $26.6 \%$ increase in root length was observed in plants grown at high substrate moisture ( $80 \%$ CC) compared with plants grown at medium moisture $(45 \%$ CC) level $(P=0.005)$. There were no differences measured in leaf chlorophyll (SPAD) within plant species in Expt. 2A and 2B (data not shown) and all plants appeared healthy.

Expt. 2C. Dissolved oxygen in substrate with top watering. The addition of oxygenated water increased the substrate DO measured at 2- and 4-cm depths (Fig. 3) from 8.6 to $14.5 \mathrm{mg} \cdot \mathrm{L}^{-1}$ (68\% increase) and 6.5 to 11.6 $\mathrm{mg} \cdot \mathrm{L}^{-1}(78 \%$ increase $)$, respectively, as the applied volume of water increased from $0 \%$ to $200 \%$ of container volume $(P=0.0001)$. Similar results were observed for the substrate DO measured in plug cells (Expt. 1D.). When a large volume of oxygenated water was applied with top watering, sufficient substrate solution was displaced, resulting in a measurable increase in the substrate DO.

The application of ambient water did not increase the substrate DO, which averaged 8.5 and $7.2 \mathrm{mg} \cdot \mathrm{L}^{-1}$ for 2- and 4-cm depths, respectively. The overall substrate DO for both water types decreased by $1.8 \mathrm{mg} \cdot \mathrm{L}^{-1}$ from the 4-cm depth compared with the $2-\mathrm{cm}$ depth $(P=0.0001)$. Decreased oxygen concentration has been measured at increasing depths in container substrate because there is likely to be decreased diffusion of gas from the substrate upper surface, and lower depths contain a greater proportion of water-filled pores (Argo et al., 1996; Dresbøll and Thorup-Kristensen, 2010; Van Iersel and Dove, 2014; Wever et al., 2001)

Expt. 2D. Dissolved oxygen in substrate with subirrigation over time. Following subirrigation, the substrate DO ranged from 7.3 to $7.7 \mathrm{mg} \cdot \mathrm{L}^{-1}$ and averaged $87.4 \%$ of saturation regardless of the water type (oxygenated or ambient), time after irrigation $(0,30,60$, and $120 \mathrm{~min})$, or measurement depth $(2,4$, or 6-cm). The substrate DO was similar between water types measured after subirrigation because there was less displacement of the substrate solution compared with increased substrate DO when top watered in Expt. 2C.

\section{Discussion}

Some published studies have found limited responses to oxygenation of irrigation water. This may have occurred when root 
zone conditions with ambient irrigation water were not sufficiently hypoxic to affect root respiration, or because an elevated DO was not maintained throughout the irrigation system and substrate. Watermelon grown in 40 - $\mathrm{L}$ perlite $(<5 \mathrm{~mm}$ diameter) bags were irrigated with oxygenated or ambient nutrient solution (Bonachela et al., 2005) and showed no differences in plant biomass, fruit yield, or fruit quality. In that study, although the DO measured at the dripper averaged 13.5 or $5.9 \mathrm{mg} \cdot \mathrm{L}^{-1}$ for oxygenated or ambient water, respectively, DO in the substrate solution was similar (4.5 or $3.7 \mathrm{mg} \cdot \mathrm{L}^{-1}$ for the two water sources). Bonachela et al. (2010) grew greenhouse tomatoes in rockwool with $40 \%$ air-filled porosity and irrigated with either oxygenated or ambient treated wastewater with average DO of 14.6 or $4.5 \mathrm{mg} \cdot \mathrm{L}^{-1}$, respectively. Dissolved oxygen measured in the center of the rockwool slab was similar for both irrigation treatments $\left(5.1\right.$ or $4.8 \mathrm{mg} \cdot \mathrm{L}^{-1}$, respectively, for oxygenated or ambient irrigation water), and similar plant biomass and yield was observed with both water types. The similar DO levels in the substrate solution and lack of plant response in both Bonachela studies may have resulted from using substrates with high air porosity. Ehret et al. (2010) conducted a series of experiments with pepper and cucumber, in cedar sawdust, perlite, and pumice and with DO of the nutrient solution ranging from 2 to 31.6 $\mathrm{mg} \cdot \mathrm{L}^{-1}$. Pepper fruit yield was unaffected by water oxygenation and cucumber fruit yield was increased by oxygenated water in one of three trials.

However, in some other published studies, oxygenation of nutrient solution has resulted in improved yield compared with plants grown in hypoxic to anoxic conditions, in addition to reduced root necrosis (Marfâ et al., 2005), increased leaf area and root mass (Holtman et al., 2005), increased macronutrient uptake (Marfà et al., 2005), and increased shelf life in cucumber (Ehret et al., 2010) and pepper (Ehret et al., 2010; Marfâ et al., 2005). For example, Lei et al. (2016) found that corn yield increased by oxygenation of irrigation water for plants grown in a completely water-logged vermiculite substrate under warm water temperature (averaging $27.7{ }^{\circ} \mathrm{C}$ ), where DO in the ambient irrigation water at times decreased to 1 $\mathrm{mg} \cdot \mathrm{L}^{-1}$ in the substrate. These completely saturated conditions differed from plant growth in peat-perlite substrate with moisture levels at or below CC in our studies.

Although, there were no effects on plant growth or rooting observed in the propagation trial (Expt. 1), we found that water held in unpressurized containers maintained supersaturated DO levels after $4.5 \mathrm{~h}$ for oxygenated water, although DO level dropped by $37 \%$ with constant stirring. Water that passed through fine mist nozzles increased the droplet surface area in contact with air, leading to an increase in DO for ambient tap water and off-gassing of oxygen in oxygenated water. As a result, misting brought both water types to the DO saturation point. The substrate DO increased (Expt. 1C) when a high volume of oxygenated water was applied to plug cells, whereas ambient tap water did not increase the substrate DO.

Plant stress symptoms for hypoxia were not observed in the container plant trial (Expt. 2A) or when Pelargonium was grown at a high moisture level (Expt. 2B), which is the likely reason that irrigating with oxygenated nutrient supplemented water did not benefit plant growth. Oxygen supply to roots can be affected by substrate porosity and irrigation management. Root substrates and growing containers are designed to have adequate air porosity for root respiration, even at CC (Argo et al., 1996; DeBoodt and Verdonck, 1971; Gislerod, 1982; Handreck and Black, 1994), and oxygen has far greater diffusion rate in air than DO in water (Colmer, 2003; Wegner, 2010). The average air porosity was $19 \%$ (Expt. 2A and $2 \mathrm{~B}$ ) for pots at $\mathrm{CC}$ and the lowest substrate DO was measured at $6.5 \mathrm{mg} \cdot \mathrm{L}^{-1}$ (Expt. 2C and 2D).

\section{Conclusion}

Injecting oxygen into irrigation water increased DO to $\approx 300 \%$ of the equilibrium saturation level of oxygen solubility in water in our study. Water in unpressurized containers held relatively stable DO levels over a 4.5-h period of time at room temperature of $24{ }^{\circ} \mathrm{C}$ for both oxygenated and tap water. However, passing irrigation water through fine propagation nozzles increased the droplet surface area, allowing for greater diffusion of oxygen. Dissolved oxygen therefore increased in ambient tap water and off-gassed in oxygenated water to bring both water types to saturation, and no difference in plant growth was observed in the propagation trial.

Oxygenating irrigation water did not benefit plant growth during subsequent growth in containers because the plants were not grown in completely water-logged and hypoxic conditions but rather had adequate air porosity in the container substrate. We conclude that the best method to provide adequate oxygen to roots is through a substrate with air-filled porosity and avoidance of overwatering. Adding oxygenated water to an already saturated container substrate is not a recommended approach to water or oxygen management.

\section{Literature Cited}

Argo, W.R., J.A. Biernbaum, and W.C. Fonteno. 1996. Root medium carbon dioxide and oxygen partial pressure for container-grown Chrysanthemum. HortScience 32:385-388.

Armstrong, W., D. Cousins, J. Armstrong, W. Turner, and P.M. Beckett. 2000. Oxygen distribution in wetland plant roots and permeability barriers to gas-exchange with the rhizospere: A microelectrode and modeling study with Phragmites australis. Ann. Bot. 86:687-703

Armstrong, W. and M.C. Drew. 2002. Root growth and metabolism under oxygen deficiency, p. 729-761. In: Y. Waisel, A. Eshel, and U. Kafkafi (eds.). Plant Roots: The Hidden Half. 3rd ed. Marcel Dekker, Inc., New York, NY.
Bonachela, S., J. Quesada, R.A. Acuña, J.J. Magán, and O. Marfâ. 2010. Oxyfertigation of greenhouse tomato crop grown in rockwool slabs and irrigated with treated wastewater: Oxygen content dynamics and crop response. Agr. Water Mgt. 97:433-438.

Bonachela, S., J.A. Vargas, and R.A. Acuña. 2005 Effect of increasing the dissolved oxygen in the nutrient solution to above-saturation levels in a greenhouse watermelon crop grown in perlite bags in a Mediterranean area. Acta Hort. 697:25-32.

Chérif, M., Y. Tirilly, and R.R. Belanger. 1997. Effect of oxygen concentration on plant growth, lipidperoxidation, and receptivity of tomato roots to Pythium under hydroponic conditions. Eur. J. Plant Pathol. 103:255-264.

Colmer, T.D. 2003. Long-distance transport of gases in plants: A perspective on internal aeration and radial oxygen loss from roots. Plant Cell Environ. 26:17-36.

Currie, J.A. 1970. Movement of gases in soil respiration. Soc. Chem. Ind. Monogr. 37:152171.

DeBoodt, M. and O. Verdonck. 1971. Physical properties of peat and peat-moulds improved by perlite and foam-plastics in relation to ornamental plant-growth. Acta Hort. 18:9-27.

Dresbøll, D.B. and K. Thorup-Kristensen. 2010. Spatial and temporal oxygen distribution measured with oxygen microsensors in growing media with different levels of compaction. Sci. Hort. 128:68-75.

Drew, M.C. 1983. Plant injury and adaptation to oxygen deficiency in the root environment: A review. Plant Soil 75:179-199.

Drew, M.C. 1988. Effects of flooding and oxygen deficiency on plant mineral nutrition, p. 115159. In: A. Lauchli and P.B. Tinker (eds.). Advances in plant nutrition, Vol. 3. Praeger, New York.

Ehret, D.L., D. Edwards, T. Helmer, W. Lin, G. Jones, M. Dorais, and A.P. Papadopoulos. 2010. Effects of oxygen-enriched nutrient solution on greenhouse cucumber and pepper production. Sci. Hort. 125:602-607.

Gislerod, H.R. 1982. Physical conditions of propagation media and their influence on the rooting of cuttings. Plant Soil 69:445-456.

Goto, E., A.J. Both, L.D. Albright, R.W. Langhans, and A.R. Leed. 1996. Effect of dissolved oxygen concentration on lettuce growth in floating hydroponics. Acta Hort. 440:205-209.

Handreck, K. and N. Black. 1994. Growing media for ornamental plants and turf. University of South Wales Press, Sydney, Australia.

Herrera, M. and J.L. Garvin. 2011. Aquaporins as gas channels. Pflugers Arch. 462:623-630.

Holtman, W., B. van Duijn, A. Blaakmeer, and C. Blok. 2005. Optimalization of oxygen levels in root systems as effective cultivation tool. Acta Hort. 697:57-64.

Hub, J.S., H. Grubmüller, and B.L. de Groot. 2009. Dynamics and energetics of permeation through aquaporins. What do we learn from molecular dynamics simulations? p. 57-76. In: E. Beitz (ed.). Aquaporins, Handbook of Experimental Pharmacology 190, SpringerVerlag, Berlin, Heidelberg.

Johnson, C.N., P.R. Fisher, J. Huang, T.H. Yeager, T.A. Obreza, R.P. Vetanovetz, W.R. Argo, and A.J. Bishko. 2013. Effect of fertilizer potential acidity and nitrogen form on the $\mathrm{pH}$ response in a peat-based substrate with three floricultural species. Sci. Hort. 162:135-143.

Lei, H., S. Bhattarai, R. Balsys, D.J. Midmore, T. Holmes, and W. Zimmerman. 2016. Temporal and spatial dimension of dissolved oxygen 
saturation with fluidic oscillator and Mazzei air injector in soil-less irrigation systems. Irrig. Sci. 34:421-430.

Lemon, E.R. 1962. Soil aeration and plant root relations. Agron. J. 54:167-170.

Luxmoore, R.J., L.H. Stolzy, and J. Letey. 1970. Oxygen diffusion in the soil-plant system I. A Model. Agron. J. 62:317-322.

Marfà, O., R. Cáceres, and S. Guri. 2005. Oxyfertigation: A new technique for soilless culture under Mediterranean conditions. Acta Hort. 697:65-72.

Morard, P. and J. Silvestre. 1996. Plant injury due to oxygen deficiency in the root environment of soilless culture: A review. Plant Soil 184:243-254.

Naasz, R., J. Caron, J. Legault, and A. Pichette. 2009. Efficiency factors for bark substrates:
Biostability, aeration, or phytotoxicity. Soil Sci. Soc. Amer. J. 73:780-791.

Santos, K.M., P.R. Fisher, T. Yeager, E.H. Simonne, H.S. Carter, and W.R. Argo. 2011. Timing of macronutrient supply during cutting propagation of Petunia. HortScience 43:475-480.

Schröder, F.-G. 1994. Technological development, plant growth and root environment of the plant plane hydroponic system. Acta Hort. 631:201-209.

Schröder, F.-G. and J.H. Lieth. 2002. Irrigation control in hydroponics, p. 263-298. In: D. Savvas and H. Passam (eds.). Hydroponic production of vegetables and ornamentals. Embryo Publications, Athens, Greece.

Van Iersel, M.W. and S.K. Dove. 2014. Temporal dynamics of oxygen concentrations in a peatperlite substrate. Acta Hort. 1034:355-361.
Vestergaard, B. 1984. Oxygen supply of roots in hydroponic systems. Proc. 6th Intl. Congr. Soilless Culture. ISOSC. p. $723-$ 738.

Wegner, L.H. 2010. Oxygen transport in waterlogged plants, p. 3-7. In: S. Mancuso and S. Shabala (eds.). Waterlogging signalling and tolerance in plants. Springer-Verlag, Berlin, Heidelberg.

Wever, G., R. Baas, J.C. Marques, and L.J. van Aanholt. 2001. Gas concentration measurement in horticultural growing media. Acta Hort. 554:149-156.

Zheng, Y., L. Wang, and M. Dixon. 2007. An upper limit for elevated root zone dissolved oxygen concentration for tomato. Sci. Hort. 113:162165 . 